Check for updates

Cite this: RSC Adv., 2018, 8, 19317

Received 12th April 2018 Accepted 21st May 2018

DOI: $10.1039 / \mathrm{c} 8 \mathrm{ra0} 3125 \mathrm{~h}$

rsc.li/rsc-advances

\section{Direct reaction between silicon and methanol over Cu-based catalysts: investigation of active species and regeneration of $\mathrm{CuCl}$ catalyst}

\author{
Aili Wang, (D) ${ }^{a}$ Mingming Zhang, ${ }^{a}$ Hengbo Yin, (D) *a Shuxin Liu, ${ }^{b}$ Mengke Liu ${ }^{a}$ \\ and Tongjie $\mathrm{Hu}^{\mathrm{a}}$
}

When a CuCl/Si mixture was pretreated at $200-240{ }^{\circ} \mathrm{C}$ in a $\mathrm{N}_{2}$ atmosphere, trimethoxysilane was predominantly formed in the direct reaction of silicon with methanol. When the pretreatment temperatures were raised to $260-340{ }^{\circ} \mathrm{C}$, tetramethoxysilane was favorably formed. The $\mathrm{Cu}_{x} \mathrm{Si}_{y} \mathrm{Cl}_{z}$ species catalyzed the reaction between silicon and methanol to trimethoxysilane. Chlorination of the spent $\mathrm{CuCl} / \mathrm{Si}$ mixture promoted the reaction between silicon and methanol to form both trimethoxysilane and tetramethoxysilane due to the recovery of the $\mathrm{CuCl}$ phase and the exposure of the metallic $\mathrm{Cu}^{0}$ phase. When $\mathrm{Cu}_{2} \mathrm{O}, \mathrm{CuO}$, and $\mathrm{Cu}^{0}$ were used as the catalysts, tetramethoxysilane was formed as the main product.

\section{Introduction}

Direct synthesis of alkoxysilanes and alkylalkoxysilanes via the reaction between silicon and an alcohol or alkene has attracted great interest from researchers. ${ }^{1}$ Among the products, trimethoxysilane and tetramethoxysilane as coupling agents instead of organochlorosilanes, are widely used for the synthesis of organosilicon products. ${ }^{2-4}$

Synthesis of trimethoxysilane via the direct reaction between silicon and methanol can be catalyzed by cuprous chloride $(\mathrm{CuCl})$ in a fixed-bed or a slurry phase reactor. Pretreatment temperature can significantly affect the formation of trimethoxysilane. ${ }^{5,6}$ It was suggested that the $\mathrm{Cu}_{3} \mathrm{Si}$ phase formed at the pretreatment temperature of $350{ }^{\circ} \mathrm{C}$ was the active site for the formation of trimethoxysilane. ${ }^{5,7}$ However, it was found that although the $\mathrm{Cu}_{3} \mathrm{Si}$ phase was not detected at pretreatment temperatures below $280{ }^{\circ} \mathrm{C}$, a high selectivity of trimethoxysilane ( $\mathrm{ca} .98 \%$ ) was obtained. Recently, researchers suggested that the $\mathrm{Cu}_{3} \mathrm{Si}$ phase itself was not a reactive intermediate, but the precursor composed of $\mathrm{Cu}-\mathrm{Si}$ complex played an important role in the reaction. ${ }^{\mathbf{8 9}}$ For the direct reaction between silicon and methanol over $\mathrm{CuCl}$ catalyst, the active species are still contradictory. On the other hand, the reaction rate between silicon and methanol over a $\mathrm{CuCl}$ catalyst in a fixed-bed reactor rapidly decreases in a short reaction time period. The practical use of a $\mathrm{CuCl}$ catalyst is limited. Therefore, direct reaction

${ }^{a}$ Faculty of Chemistry and Chemical Engineering, Jiangsu University, Zhenjiang 212013, China. E-mail: yin@ujs.edu.cn; Tel: +86-511-88787591

${ }^{b}$ School of Chemistry and Chemical Engineering, Mianyang Normal University, Mianyang 621000, China between silicon and methanol over a $\mathrm{CuCl}$ catalyst is still worthy of investigation.

Tetramethyoxysilane was formed as a byproduct in the direct reaction between silicon and methanol over a $\mathrm{CuCl}$ catalyst. ${ }^{5,7} \mathrm{It}$ was also formed as the main product when the reaction was carried out over metallic $\mathrm{Cu}^{0}$ and $\mathrm{Cu}_{2} \mathrm{O}$ catalysts. ${ }^{\mathbf{8} 10}$ It was suggested that the formation of tetramethoxysilane originated from the reaction between methanol and trimethoxysilane in series catalyzed by metallic $\mathrm{Cu}^{0}$ active sites. ${ }^{8}$ The detailed catalytic process is unclear and worthy of further investigation.

In the present work, the reactions between silicon and methanol over $\mathrm{CuCl}, \mathrm{Cu}_{2} \mathrm{O}, \mathrm{CuO}$, and bulk metallic $\mathrm{Cu}^{0}$ catalysts and the regeneration of $\mathrm{CuCl}$ catalyst were investigated. The chemical structures of these catalysts after pretreatment and reaction were investigated by XRD, XPS, and XAES techniques. The active sites and reaction mechanisms over these catalysts were discussed below.

\section{Experimental}

\subsection{Materials}

Methanol (99.5\%), cuprous chloride (97\%), cuprous oxide (95\%), copper oxide (99\%), and bulk metallic copper powder $(150 \mu \mathrm{m})$ were of reagent grade and were purchased from Sinopharm Chemical Reagent Co., Ltd. Silicon powder (>99.5\%) was supplied by Jiangsu Hongda New Materials Co., Ltd. The materials were used as received without further purification.

\subsection{Characterization}

XRD patterns of the samples were recorded on a XRD-6100Lab diffractometer with a graphite monochromator using the $\mathrm{Cu}$ 
$\mathrm{K} \alpha$ radiation $(\lambda=1.54056 \AA)$ at the scanning speed of $2^{\circ} \mathrm{min}^{-1}$. $\mathrm{X}$-ray photoelectron spectra (XPS) and X-ray Auger Electron Spectra (XAES) of the samples were obtained on an X-ray photoelectron spectroscopy/ESCA spectrometer (K-ALPHA, Thermo Fisher Scientific) using Al $\mathrm{K} \alpha$ radiation $(1486.68 \mathrm{eV}$ ). The binding energies were calculated with respect to $\mathrm{C} 1 \mathrm{~s}$ peak of contaminated carbon at $284.6 \mathrm{eV}$.

\subsection{Catalytic text}

Given amounts of silicon powder and catalyst $\left(\mathrm{CuCl}, \mathrm{Cu}_{2} \mathrm{O}, \mathrm{CuO}\right.$ or bulk metallic $\mathrm{Cu}^{0}$ ) were mixed in a high-speed, multifunction crusher (2000 rpm) for $2 \mathrm{~min}$. The particle sizes of the catalyst/Si mixture ranged from 50 to 200 mesh. The reaction was carried out in a fixed-bed reactor with diameter and length of $1.8 \mathrm{~cm}$ and $50 \mathrm{~cm}$. $20 \mathrm{~mL}$ of glass beads (diameter, 3 $\mathrm{mm}$ ) were added on the top of catalyst/Si bed to evaporate methanol feed into gas phase. A $\mathrm{N}_{2}$ stream (99.999\%) with

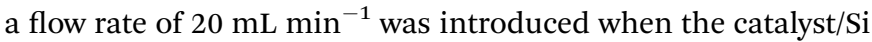
mixture was pretreated at different temperatures. For the catalytic reaction between silicon and methanol, methanol with a flow rate of $6 \mathrm{~mL} \mathrm{~h}^{-1}$ was pumped into the reactor with a constant flow pump (TBP 1010, Tauto). The resulting reaction products were condensed and collected in an ice-water trap. The reaction products were analyzed by gas chromatography (Agilent $7890 \mathrm{~A})$ with a capillary column $(\mathrm{SE}-54,0.32 \times 30)$ and an FID detector.

\section{Results and discussion}

\subsection{Structures of $\mathrm{CuCl} / \mathrm{Si}$ mixtures after pretreatment and reaction}

3.1.1. XRD analysis. The effects of pretreatment and reaction on the chemical structures of the $\mathrm{CuCl} / \mathrm{Si}$ mixtures were investigated by ex situ XRD technique. The XRD spectra of the mixtures pretreated at different temperatures in a $\mathrm{N}_{2}$ stream show that the characteristic peaks of silicon appeared at $(2 \theta)$ $47.3,56.1,69.1$, and $76.4^{\circ}$, respectively, which were consistent with those of the standard silicon sample (JCPDs 27-1402) (Fig. 1a). The main characteristic peaks of the $\mathrm{CuCl}$ catalyst were overlapped by those of silicon. A weak peak at $(2 \theta) 33.1^{\circ}$ ascribed to that of the standard $\mathrm{CuCl}$ sample (JCPDs 06-0344) was observed for the mixtures pretreated at the lower temperatures of $200-240{ }^{\circ} \mathrm{C}$ (Fig. 1a, inset). The peak intensities of the $\mathrm{CuCl}$ phase decreased with pretreatment temperature, indicating that pretreatment at $200-240{ }^{\circ} \mathrm{C}$ caused the reaction between $\mathrm{CuCl}$ and silicon to form surface $\mathrm{Cu}-\mathrm{Si}-\mathrm{Cl}$ complexes.

$$
\mathrm{CuCl}+\mathrm{Si} \rightarrow \mathrm{Cu}-\mathrm{Si}-\mathrm{Cl} \text { complex }+\mathrm{SiCl}_{4}\left(200-240{ }^{\circ} \mathrm{C}\right)
$$

There was no $\mathrm{CuCl}$ peak at $(2 \theta) 33.1^{\circ}$ detected at the pretreatment temperatures of $260-340{ }^{\circ} \mathrm{C}$. The XRD peak appearing at $43.3^{\circ}$ ascribed to the characteristic peak of the standard metallic $\mathrm{Cu}^{0}$ (JCPDs 04-0836) was detected at 260$340{ }^{\circ} \mathrm{C}$. The intensities of the metallic $\mathrm{Cu}^{0}$ peaks slightly increased with pretreatment temperature. The intensity ratios of metallic $\mathrm{Cu}^{0}(111)$ peak to $\mathrm{Si}(220)$ peak were in a range of
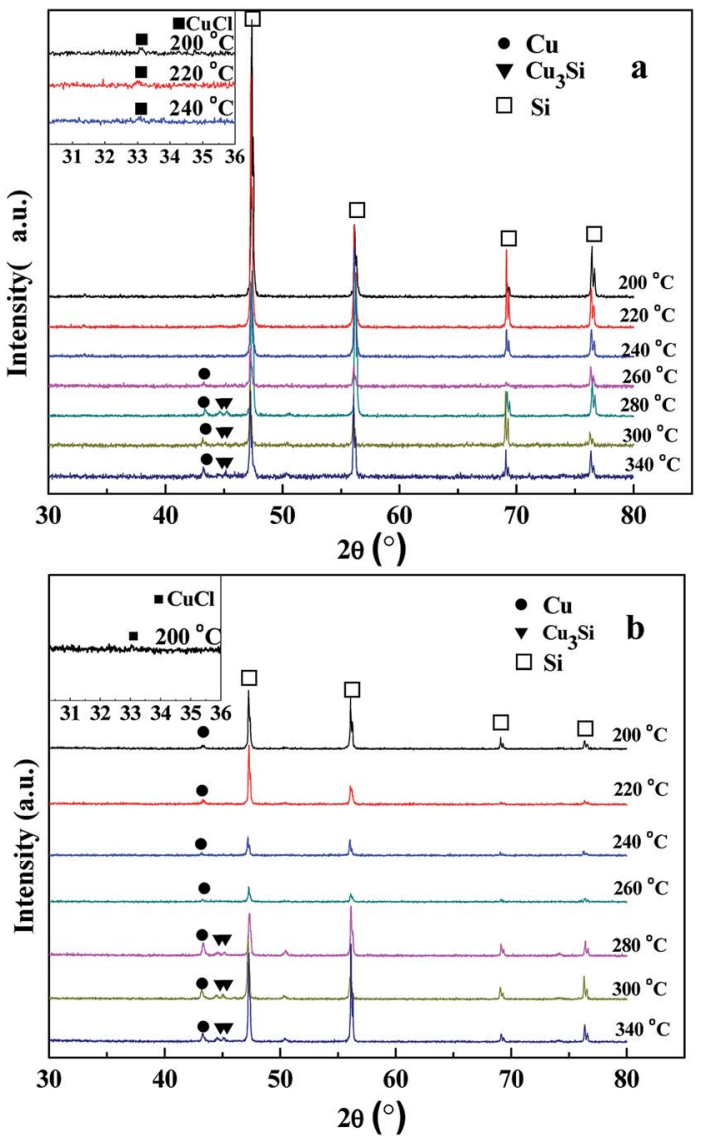

Fig. 1 XRD spectra of the CuCl/Si mixtures after pretreatment and reaction. (a) The $\mathrm{CuCl} / \mathrm{Si}$ mixtures were pretreated at different temperatures of $200-340{ }^{\circ} \mathrm{C}$ for $2 \mathrm{~h}$ in a $\mathrm{N}_{2}$ stream $\left(20 \mathrm{~mL} \mathrm{~min}{ }^{-1}\right.$ ). (b) After pretreating at a given temperature, the $\mathrm{CuCl} / \mathrm{Si}$ mixtures reacted with methanol at 220, 240, and $260{ }^{\circ} \mathrm{C}$ for $1 \mathrm{~h}$, respectively. The reaction conditions: $\mathrm{CuCl} / \mathrm{Si}$ mixture, $40 \mathrm{~g}$; $\mathrm{CuCl} / \mathrm{Si}$ weight ratio, 8 : 100; methanol flow rate, $6 \mathrm{~mL} \mathrm{~h}^{-1}$. The insets are the amplified XRD peaks of $\mathrm{CuCl}$ phase.

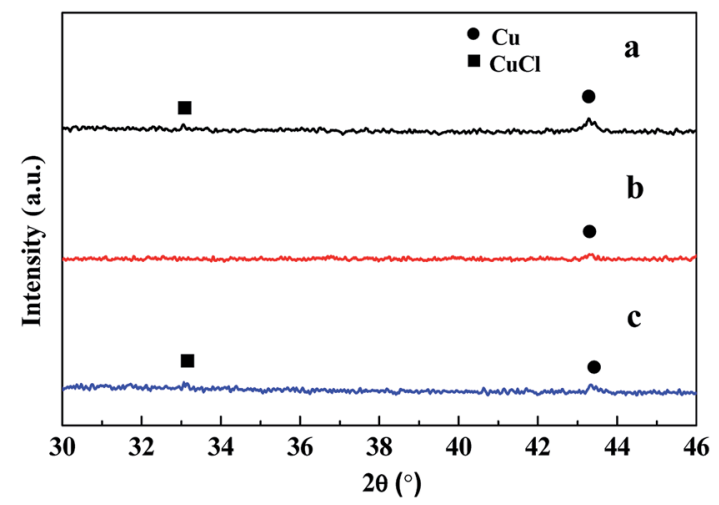

Fig. 2 XRD spectra of the $\mathrm{CuCl} / \mathrm{Si}$ mixtures under different reaction conditions. (a) The CuCl/Si mixture was pretreated at $200^{\circ} \mathrm{C}$ for $2 \mathrm{~h}$ in a $\mathrm{N}_{2}$ stream $\left(20 \mathrm{~mL} \mathrm{~min}^{-1}\right)$ and then reacted with methanol at 220, 240 , and $260{ }^{\circ} \mathrm{C}$ for $1 \mathrm{~h}$, respectively. (b) The CuCl/Si mixture reacted with methanol at $240{ }^{\circ} \mathrm{C}$ for $12 \mathrm{~h}$. (c) After reacting for $12 \mathrm{~h}$, the spent $\mathrm{CuCl} / \mathrm{Si}$ mixture was chlorinated with $\mathrm{HCl}\left(40 \mathrm{~mL} \mathrm{~min}^{-1}\right)$ at $280^{\circ} \mathrm{C}$ for $1.5 \mathrm{~h}$. Reaction conditions: $\mathrm{CuCl} / \mathrm{Si}$ weight ratio of $8: 100,40 \mathrm{~g}$; methanol flow rate, $6 \mathrm{~mL} \mathrm{~h}^{-1}$. 

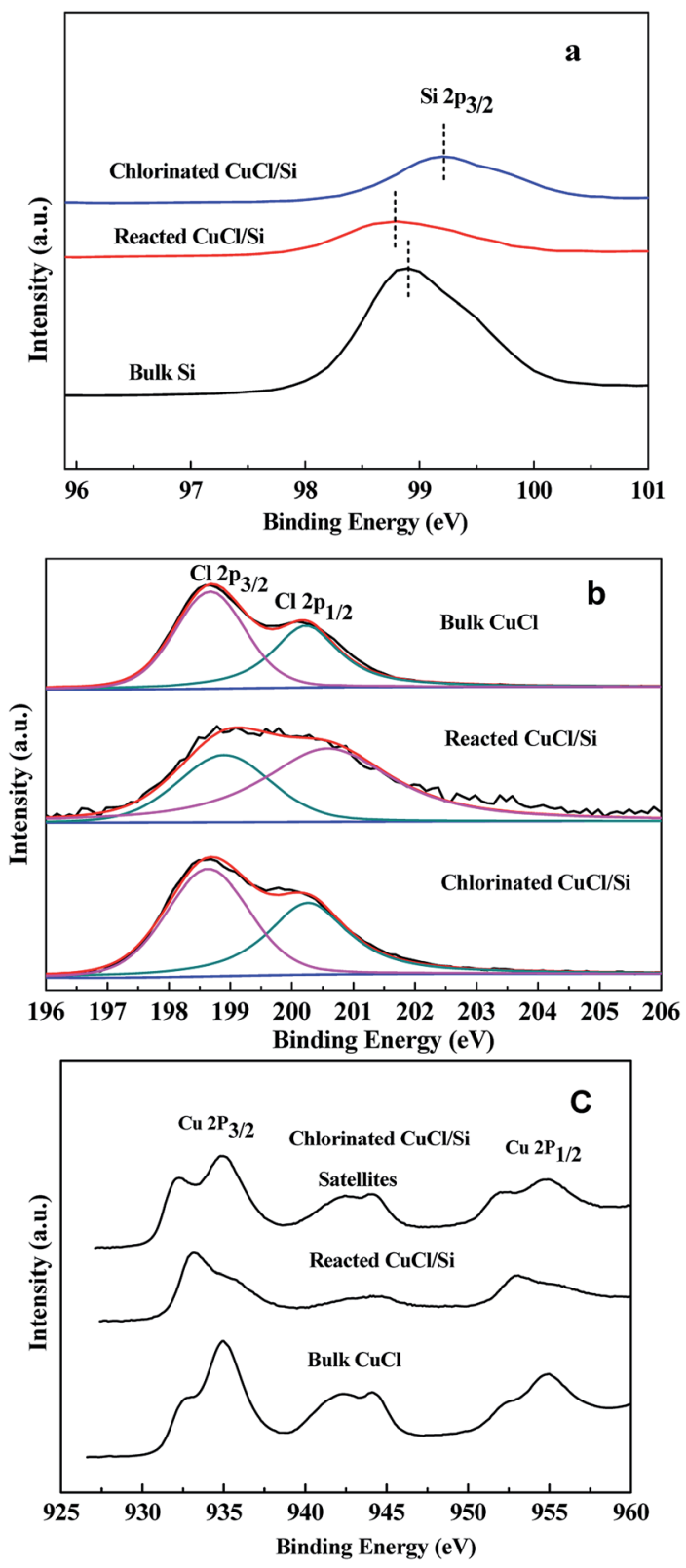

Fig. 3 XPS of $\mathrm{Si} 2 \mathrm{p}, \mathrm{Cl} 2 \mathrm{p}$, and $\mathrm{Cu} 2 \mathrm{p}$ of the bulk Si, bulk $\mathrm{CuCl}$, reacted $\mathrm{CuCl} / \mathrm{Si}$, and chlorinated $\mathrm{CuCl} / \mathrm{Si}$ samples. Reaction conditions: $\mathrm{CuCl}$ Si weight ratio of $8: 100,40 \mathrm{~g}$; methanol flow rate, $6 \mathrm{~mL} \mathrm{~h}^{-1}$. The mixture reacted at $240{ }^{\circ} \mathrm{C}$ for $12 \mathrm{~h}$, denoted as reacted $\mathrm{CuCl} / \mathrm{Si}$. After reacting for $12 \mathrm{~h}$, the mixture was chlorinated with $\mathrm{HCl}\left(40 \mathrm{~mL} \mathrm{~min}^{-1}\right)$ at $280{ }^{\circ} \mathrm{C}$ for $1.5 \mathrm{~h}$, denoted as chlorinated $\mathrm{CuCl} / \mathrm{Si}$.

$5.1: 100$ to $12.7: 100$. When the pretreatment temperatures were $280-340{ }^{\circ} \mathrm{C}$, the XRD peaks at 44.5 (012) and $45.1^{\circ}$ (300) ascribed to those of the $\mathrm{Cu}_{3} \mathrm{Si}$ phase (JCPDS 51-0916) were observed. The intensity ratios of $\mathrm{Cu}_{3} \mathrm{Si}(012)$ and (300) peaks to Si (220) peak ranged from $2.5: 100$ to $4.8: 100$ and from $2.8: 100$ to $6.6: 100$, respectively. The results revealed that high pretreatment temperature caused the reaction between $\mathrm{CuCl}$ and silicon to form metallic $\mathrm{Cu}^{0}$ and $\mathrm{Cu}_{3} \mathrm{Si}$ phases as follows. ${ }^{11}$

$$
4 \mathrm{CuCl}+\mathrm{Si}=4 \mathrm{Cu}+\mathrm{SiCl}_{4}\left(260-340^{\circ} \mathrm{C}\right)
$$

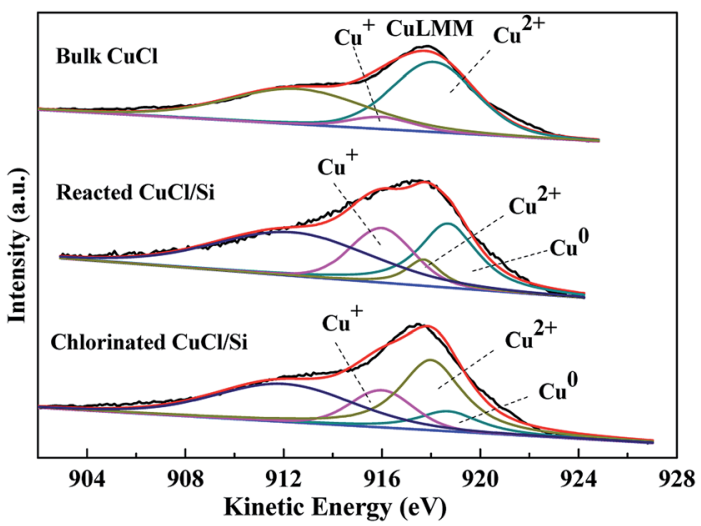

Fig. 4 XAES of $\mathrm{Cu} \mathrm{LMM}$ of the bulk $\mathrm{CuCl}$, reacted $\mathrm{CuCl} / \mathrm{Si}$, and chlorinated $\mathrm{CuCl} / \mathrm{Si}$ samples. The $\mathrm{CuCl} / \mathrm{Si}$ mixture $(40 \mathrm{~g}, \mathrm{CuCl} / \mathrm{Si}$ weight ratio of $8: 100)$ reacted with methanol $\left(6 \mathrm{~mL} \mathrm{~h}^{-1}\right)$ at $240{ }^{\circ} \mathrm{C}$ for $12 \mathrm{~h}$, denoted as reacted $\mathrm{CuCl} / \mathrm{Si}$. After reacting for $12 \mathrm{~h}$, the spent $\mathrm{CuCl} / \mathrm{Si}$ mixture was chlorinated with $\mathrm{HCl}\left(40 \mathrm{~mL} \mathrm{~min}^{-1}\right)$ at $280{ }^{\circ} \mathrm{C}$ for $1.5 \mathrm{~h}$, denoted as chlorinated $\mathrm{CuCl} / \mathrm{Si}$.

$$
12 \mathrm{CuCl}+7 \mathrm{Si}=4 \mathrm{Cu}_{3} \mathrm{Si}+3 \mathrm{SiCl}_{4}\left(280-340{ }^{\circ} \mathrm{C}\right)
$$

After taking part in the reaction between silicon and methanol, the $\mathrm{CuCl}$ phase was only observed in the $\mathrm{CuCl} / \mathrm{Si}$ mixture pretreated at $200{ }^{\circ} \mathrm{C}$ (Fig. $1 \mathrm{~b}$, inset). The metallic $\mathrm{Cu}^{0}$ phase (JCPDs 04-0836) appeared in the mixtures pretreated at 200$340{ }^{\circ} \mathrm{C}$, whereas the $\mathrm{Cu}_{3} \mathrm{Si}$ phase (JCPDs 51-0916) appeared in the mixtures pretreated at $280-340{ }^{\circ} \mathrm{C}$ (Fig. 1b). The results revealed that $\mathrm{CuCl}$ took part in the reaction and the metallic $\mathrm{Cu}^{0}$ phase was formed in the reaction process. The $\mathrm{Cu}_{3} \mathrm{Si}$ phase was formed due to the pretreatment at high temperature rather than via the reaction.

When the $\mathrm{CuCl} / \mathrm{Si}$ mixture was pretreated at $200{ }^{\circ} \mathrm{C}$ for $2 \mathrm{~h}$ in a $\mathrm{N}_{2}$ atmosphere and then reacted at 220,240 , and $260{ }^{\circ} \mathrm{C}$ for $1 \mathrm{~h}$, respectively, the metallic $\mathrm{Cu}^{0}$ phase appeared and the $\mathrm{CuCl}$ phase remained (Fig. 2a). After reacting at $240{ }^{\circ} \mathrm{C}$ for a longer time period of $12 \mathrm{~h}$, metallic $\mathrm{Cu}^{0}$ was formed, but the $\mathrm{CuCl}$ phase disappeared (Fig. 2b), indicating that the $\mathrm{CuCl}$ phase took part in the reaction. When the spent $\mathrm{CuCl} / \mathrm{Si}$ mixture was chlorinated in an $\mathrm{HCl}$ stream, in addition to the presence of the metallic $\mathrm{Cu}^{0}$ phase, the $\mathrm{CuCl}$ phase appeared again (Fig. 2c). The chlorination converted the copper species to $\mathrm{CuCl}$.

3.1.2. XPS and XAES analyses. The surface chemical structures of the bulk $\mathrm{CuCl}$, bulk $\mathrm{Si}$, reacted $\mathrm{CuCl} / \mathrm{Si}$, and chlorinated $\mathrm{CuCl} / \mathrm{Si}$ were detected using the ex situ XPS technique. The X-ray photoelectron spectra of $\mathrm{Si} 2 \mathrm{p}, \mathrm{Cl} 2 \mathrm{p}$, and $\mathrm{Cu}$ $2 p$ are shown in Fig. 3.

The binding energies of Si $2 \mathrm{p}_{3 / 2}$ of the bulk Si, reacted $\mathrm{CuCl} /$ $\mathrm{Si}$, and chlorinated $\mathrm{CuCl} / \mathrm{Si}$ samples were 98.9, 98.8, and $99.2 \mathrm{eV}$, respectively (Fig. 3a). The Si $2 \mathrm{p}_{3 / 2}$ peak of the reacted $\mathrm{CuCl} / \mathrm{Si}$ mixture shifted by $0.1 \mathrm{eV}$ to a lower binding energy as compared to that of the bulk $\mathrm{Si}$, revealing that there was an interaction between bulk $\mathrm{Si}$ and $\mathrm{CuCl}$ during the reaction process. However, chlorination caused a positive shift of the $\mathrm{Si}$ $2 \mathrm{p}_{3 / 2}$ peak of the chlorinated $\mathrm{CuCl} / \mathrm{Si}$ mixture, probably due to surface-interacted $\mathrm{Cu}^{+}$being chlorinated to $\mathrm{CuCl}$. 
Table 1 Surface copper components based on Cu LMM deconvolution and surface atomic ratios of Cl to Cu based on XPS analysis

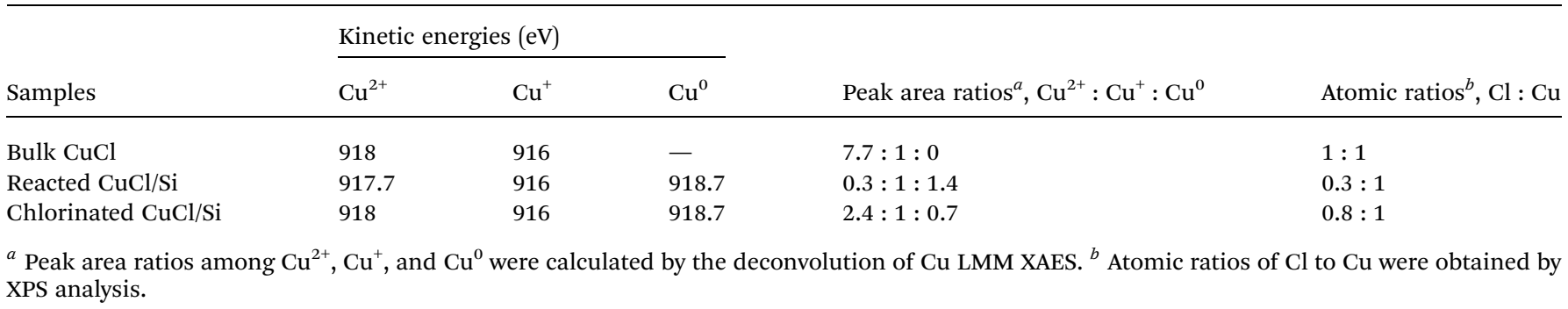

${ }^{a}$ Peak area ratios among $\mathrm{Cu}^{2+}, \mathrm{Cu}^{+}$, and $\mathrm{Cu}^{0}$ were calculated by the deconvolution of $\mathrm{Cu}$ LMM XAES. ${ }^{b}$ Atomic ratios of $\mathrm{Cl}$ to $\mathrm{Cu}$ were obtained by

XPS a

$$
\begin{aligned}
& \text { 1. Reactions between } \mathrm{CuCl} \text { and bulk } \mathrm{Si} \text { at } 200-260^{\circ} \mathrm{C} \\
& x \mathrm{CuCl}+y \mathrm{Si} \stackrel{-\mathrm{Cl}^{-}}{\longrightarrow} \mathrm{Cu}_{x} \mathrm{Si}_{y} \mathrm{Cl}_{z} \\
& \mathrm{Cu}_{x} \mathrm{Si}_{y} \mathrm{Cl}_{z} \stackrel{-\mathrm{Cl}^{-},-\mathrm{Si}}{\longrightarrow} \mathrm{Cu}_{x} \mathrm{Si}_{m} \mathrm{Cl}_{n} \\
& \mathrm{Cu}_{x} \mathrm{Si}_{m} \mathrm{Cl}_{n} \longrightarrow(x-i) \mathrm{Cu}^{0}+\mathrm{Cu}_{i} \mathrm{Si}_{m} \mathrm{Cl}_{n} \\
& \text { 2. Chlorination reaction } \\
& \mathrm{Cu}_{i} \mathrm{Si}_{m} \mathrm{Cl}_{n}+\mathrm{HCl} \longrightarrow \mathrm{CuCl}+\mathrm{H}_{2}+\mathrm{Cu}-\mathrm{Si}-\mathrm{Cl}_{\text {complex }} \text { (1) } \\
& \mathrm{Cu}-\mathrm{Si}-\mathrm{Cl}_{\text {complex }}+\mathrm{CuCl} \longrightarrow \mathrm{Cu}_{x} \mathrm{Si}_{y} \mathrm{Cl}_{z}
\end{aligned}
$$

Scheme 1 Reactions between $\mathrm{CuCl}$ and bulk Si and the chlorination reaction.

The binding energies of $\mathrm{Cl} 2 \mathrm{p}_{3 / 2}$ and $\mathrm{Cl} 2 \mathrm{p}_{1 / 2}$ of $\mathrm{Cl}^{-}$of the bulk $\mathrm{CuCl}$, reacted $\mathrm{CuCl} / \mathrm{Si}$, and chlorinated $\mathrm{CuCl} / \mathrm{Si}$ samples were $c a .198 .7$ and $200.3 \mathrm{eV}$, respectively (Fig. 3b). According to the deconvolution of the $\mathrm{Cl} 2 \mathrm{p}_{3 / 2}$ and $\mathrm{Cl} 2 \mathrm{p}_{1 / 2}$ peaks, the area ratios of the $\mathrm{Cl} 2 \mathrm{p}_{3 / 2}$ peak to the $\mathrm{Cl} 2 \mathrm{p}_{1 / 2}$ peak for the three samples were $1: 0.8,1: 1.9$, and $1: 0.8$, respectively, revealing that there was an interaction between $\mathrm{Si}$ and $\mathrm{Cl}$ during the reaction process. After chlorination, the $\mathrm{CuCl}$ phase was recovered because the bulk $\mathrm{CuCl}$ and chlorinated $\mathrm{CuCl} / \mathrm{Si}$ samples had the same area ratios of $\mathrm{Cl} 2 \mathrm{p}_{3 / 2}$ to $\mathrm{Cl} 2 \mathrm{p}_{1 / 2}$.

The $\mathrm{Cu} 2 \mathrm{p}_{3 / 2}$ and $\mathrm{Cu} 2 \mathrm{p}_{1 / 2}$ peaks of the bulk $\mathrm{CuCl}$, reacted $\mathrm{CuCl} / \mathrm{Si}$, and chlorinated $\mathrm{CuCl} / \mathrm{Si}$ samples were doublet (Fig. 3c). The presence of a satellite peak at $c a .942 .5 \mathrm{eV}$ for the three samples indicated the presence of $\mathrm{Cu}^{2+}$ species. ${ }^{12}$ The $\mathrm{Cu} 2 \mathrm{p}_{3 / 2}$ and $\mathrm{Cu} 2 \mathrm{p}_{1 / 2}$ peaks at $c a .935$ and $955 \mathrm{eV}$ were ascribed to those of $\mathrm{Cu}^{2+}$ species, whereas the $\mathrm{Cu} 2 \mathrm{p}_{3 / 2}$ and $\mathrm{Cu} 2 \mathrm{p}_{1 / 2}$ peaks at 932.4 and $952.3 \mathrm{eV}$ were ascribed to those of $\mathrm{Cu}^{+}$and/or metallic $\mathrm{Cu}^{0}$ species. ${ }^{13-16}$ The XPS analysis revealed that the three samples contained $\mathrm{Cu}^{2+}, \mathrm{Cu}^{+}$and/or $\mathrm{Cu}^{0}$ species. The presence of the $\mathrm{Cu}^{2+}$ species is observed because $\mathrm{CuCl}$ is easily oxidized when it is exposed to air during the ex situ sample characterization process. ${ }^{17}$

Considering that $\mathrm{Cu}^{+}$and metallic $\mathrm{Cu}^{0}$ have similar binding energies, it is difficult to distinguish them based on $\mathrm{Cu} 2 \mathrm{p}$ spectra. X-ray excited Auger Electron Spectroscopy (XAES) was used to determine the surface compositions of the $\mathrm{Cu}^{2+}, \mathrm{Cu}^{+}$, and $\mathrm{Cu}^{0}$ species. ${ }^{13,16,18-20}$ The $\mathrm{Cu}$ LMM XAES of the bulk $\mathrm{CuCl}$, reacted $\mathrm{CuCl} / \mathrm{Si}$, and chlorinated $\mathrm{CuCl} / \mathrm{Si}$ samples are shown in Fig. 4. Literatures report that the XAES peaks of $\mathrm{Cu}^{+}, \mathrm{Cu}^{2+}$, and $\mathrm{Cu}^{0}$ species are centered at 916, 918, and $918.7 \mathrm{eV}$, respectively. ${ }^{13,16,18-20}$ Therefore, we chose Gaussian-Lorentzian bands with peak positions at 916, 917.7-918, and 918.7 eV corresponding to $\mathrm{Cu}^{+}, \mathrm{Cu}^{2+}$, and $\mathrm{Cu}^{0}$ species, and the XAES peaks were deconvoluted into three symmetrical peaks of $\mathrm{Cu}^{+}, \mathrm{Cu}^{2+}$, and $\mathrm{Cu}^{0}$ species by using a XPSPEAK41 software. Considering that a shoulder peak appeared at $912 \mathrm{eV}$, an extra GaussianLorentzian band with the peak position at $c a .912 \mathrm{eV}$ was used to eliminate the effect of other orbital electrons on the XAES.

According to the deconvolution results, the surface copper species of the bulk $\mathrm{CuCl}$ were composed of $\mathrm{Cu}^{2+}$ and $\mathrm{Cu}^{+}$ components (Fig. 4). The surface copper species of the reacted $\mathrm{CuCl} / \mathrm{Si}$ and chlorinated $\mathrm{CuCl} / \mathrm{Si}$ mixtures were composed of $\mathrm{Cu}^{2+}, \mathrm{Cu}^{+}$, and $\mathrm{Cu}^{0}$ components. After taking part in the reaction, in addition to the formation of the metallic $\mathrm{Cu}^{0}$ component, the surface $\mathrm{Cu}^{2+}$ content of the reacted $\mathrm{CuCl} / \mathrm{Si}$ mixture was obviously less than that of the bulk $\mathrm{CuCl}$, but the surface $\mathrm{Cu}^{+}$content of the reacted $\mathrm{CuCl} / \mathrm{Si}$ mixture was larger than that of the bulk $\mathrm{CuCl}$, indicating that $\mathrm{Cu}^{2+}$ was reduced to copper species with lower valence states (Table 1). After chlorination, the total content of surface $\mathrm{Cu}^{2+}$ and $\mathrm{Cu}^{+}$species of the chlorinated $\mathrm{CuCl} / \mathrm{Si}$ mixture increased as compared to that of the reacted $\mathrm{CuCl} / \mathrm{Si}$ mixture. Considering that the surface $\mathrm{Cu}^{2+}$ species of the chlorinated $\mathrm{CuCl} / \mathrm{Si}$ mixture could be attributed to the oxidation of $\mathrm{Cu}^{+}$during the sample characterization process in air, ${ }^{17}$ it was reasonable to suggest that chlorination increased the surface $\mathrm{Cu}^{+}$content.

The XPS analysis revealed that the surface atomic ratio of $\mathrm{Cl}$ to $\mathrm{Cu}$ in the reacted $\mathrm{CuCl} / \mathrm{Si}$ mixture was lower than that in the bulk $\mathrm{CuCl}$ (Table 1). Chlorination of the reacted $\mathrm{CuCl} / \mathrm{Si}$ mixture increased the surface atomic ratio of $\mathrm{Cl}$ to $\mathrm{Cu}$. It could be explained as follows. During the reaction process, $\mathrm{CuCl}$ crystallites reacted with silicon to form $\mathrm{Cu}_{x} \mathrm{Si}_{y} \mathrm{Cl}_{z}$ species. Furthermore, $\mathrm{Cl}^{-}$from the $\mathrm{Cu}_{x} \mathrm{Si}_{y} \mathrm{Cl}_{z}$ species reacted with $\mathrm{Si}$ and/or methanol, removing it from the active species. This process caused the decrease in $\mathrm{Cl}^{-}$content of $\mathrm{Cu}_{x} \mathrm{Si}_{y} \mathrm{Cl}_{z}$ active species. With the consumption of $\mathrm{Cl}^{-}$, metallic $\mathrm{Cu}^{0}$ was formed. However, chlorination treatment caused the formation of $\mathrm{CuCl}$ and probably recovered the $\mathrm{Cu}_{x} \mathrm{Si}_{y} \mathrm{Cl}_{z}$ active species. The reactions are suggested in Scheme 1.

\subsection{Chemical structures of $\mathrm{Cu}_{2} \mathrm{O} / \mathrm{Si}, \mathrm{CuO} / \mathrm{Si}$, and $\mathrm{Cu}^{0} / \mathrm{Si}$ mixtures after pretreatment and reaction}

3.2.1. XRD analysis. When $\mathrm{Cu}_{2} \mathrm{O}$ and $\mathrm{CuO}$ were used as the catalysts, $\mathrm{Cu}_{2} \mathrm{O}$ and $\mathrm{CuO}$ phases existed in the pretreated samples, respectively (Fig. $5 \mathrm{a}$ and b). However, after reacting at $220-260{ }^{\circ} \mathrm{C}$ for $3 \mathrm{~h}$, the metallic $\mathrm{Cu}^{\circ}$ phase was formed with the 

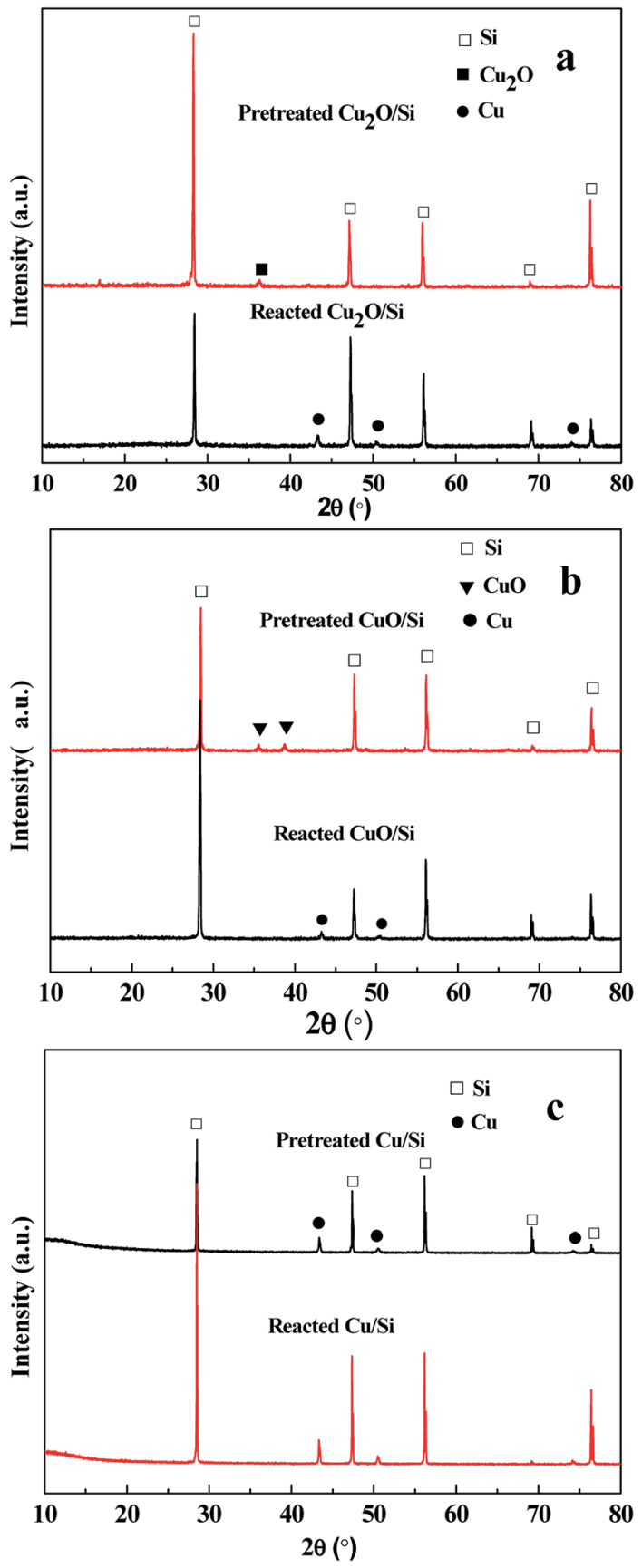

Fig. 5 XRD spectra of (a) $\mathrm{Cu}_{2} \mathrm{O} / \mathrm{Si}$, (b) $\mathrm{CuO} / \mathrm{Si}$, and (c) $\mathrm{Cu}^{0} / \mathrm{Si}$ mixtures after pretreatment and reaction. These mixtures were pretreated at $240{ }^{\circ} \mathrm{C}$ for $2 \mathrm{~h}$ in a $\mathrm{N}_{2}$ stream $\left(20 \mathrm{~mL} \mathrm{~min}^{-1}\right)$ and then reacted at 220 , 240 , and $260^{\circ} \mathrm{C}$ for $1 \mathrm{~h}$, respectively. The reaction conditions: catalyst/ $\mathrm{Si}, 40 \mathrm{~g}$; weight ratios of $\mathrm{Cu}_{2} \mathrm{O}, \mathrm{CuO}$, and $\mathrm{Cu}^{0}$ to $\mathrm{Si}, 5: 100,5: 100$, and 8 : 100; methanol flow rate, $6 \mathrm{~mL} \mathrm{~h}^{-1}$.

disappearance of the $\mathrm{Cu}_{2} \mathrm{O}$ and $\mathrm{CuO}$ phases, indicating that $\mathrm{Cu}_{2} \mathrm{O}$ and $\mathrm{CuO}$ were reduced to metallic $\mathrm{Cu}^{0}$ in the reaction process. When metallic $\mathrm{Cu}^{0}$ was used as the catalyst, after pretreatment and reaction, the metallic $\mathrm{Cu}^{0}$ phase did not change (Fig. 5c). No other phases, such as $\mathrm{Cu}-\mathrm{Si}$ compounds, were detected by XRD analysis.

3.2.2. XPS and XAES analyses. The $\mathrm{Si} 2 \mathrm{p}$ and $\mathrm{Cu} 2 \mathrm{p}$ spectra of the bulk $\mathrm{Si}$, reacted $\mathrm{Cu}_{2} \mathrm{O} / \mathrm{Si}$, reacted $\mathrm{CuO} / \mathrm{Si}$, and reacted $\mathrm{Cu}$ /
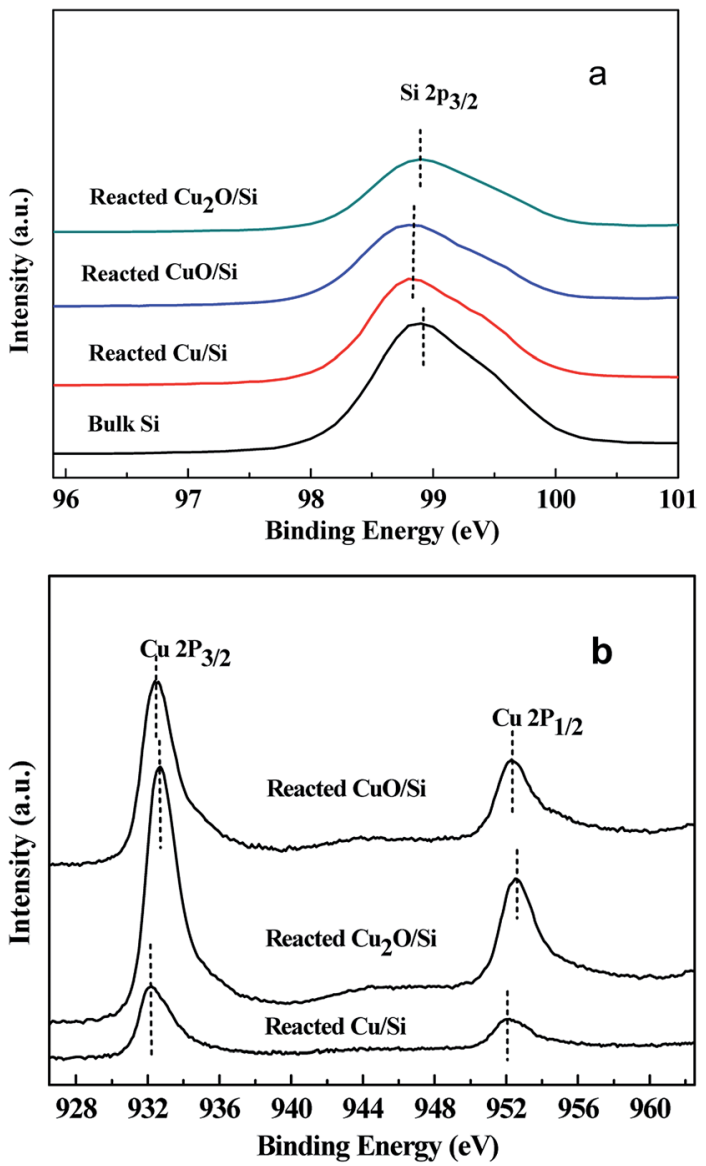

Fig. 6 The XPS of (a) Si $2 p$ and (b) $\mathrm{Cu} 2 \mathrm{p}$ of the reacted $\mathrm{Cu}_{2} \mathrm{O} / \mathrm{Si}$, reacted $\mathrm{CuO} / \mathrm{Si}$, and reacted $\mathrm{Cu} / \mathrm{Si}$ mixtures.

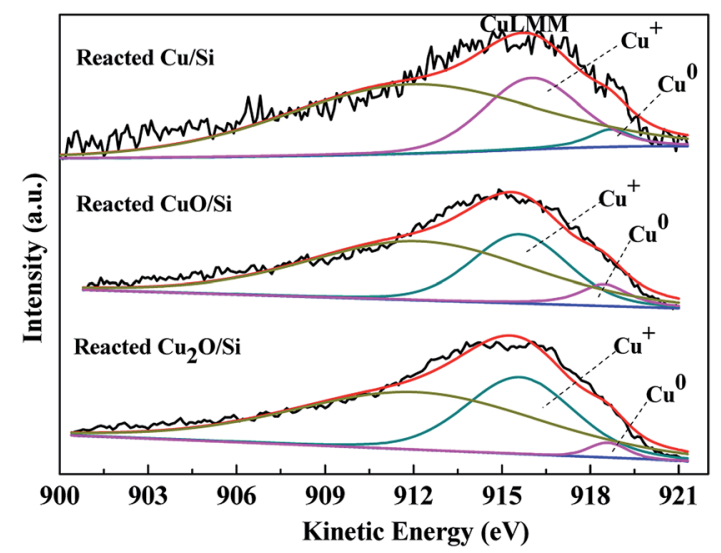

Fig. 7 The XAES of Cu LMM of the reacted $\mathrm{Cu} / \mathrm{Si}$, reacted $\mathrm{CuO} / \mathrm{Si}$, and reacted $\mathrm{Cu}_{2} \mathrm{O} / \mathrm{Si}$ samples.

Si samples are shown in Fig. 6 . The $\mathrm{Si} 2 \mathrm{p}_{3 / 2}$ peaks of the reacted $\mathrm{Cu}_{2} \mathrm{O} / \mathrm{Si}$, reacted $\mathrm{CuO} / \mathrm{Si}$, and reacted $\mathrm{Cu} / \mathrm{Si}$ samples slightly shifted by $0.1 \mathrm{eV}$ to a lower binding energy as compared with that of the bulk Si sample (Fig. 6a), indicating that there was a weak interaction between copper species and Si surface.

The binding energies of $\mathrm{Cu} 2 \mathrm{p}_{3 / 2}$ and $\mathrm{Cu} 2 \mathrm{p}_{1 / 2}$ of the reacted $\mathrm{Cu}_{2} \mathrm{O} / \mathrm{Si}$, reacted $\mathrm{CuO} / \mathrm{Si}$, and reacted $\mathrm{Cu} / \mathrm{Si}$ mixtures were $c a$. 
Table 2 Surface Cu components based on Cu LMM deconvolution

Kinetic energies $(\mathrm{eV})$

\begin{tabular}{llll} 
Samples & $\mathrm{Cu}^{+}$ & $\mathrm{Cu}^{0}$ & Peak area ratios ${ }^{a}, \mathrm{Cu}^{+}: \mathrm{Cu}^{0}$ \\
\hline Reacted $\mathrm{Cu} / \mathrm{Si}$ & 916 & 918.7 & $6.8: 1$ \\
Reacted $\mathrm{Cu} 2 \mathrm{O} / \mathrm{Si}$ & 915.6 & 918.6 & $14.7: 1$ \\
Reacted $\mathrm{CuO} / \mathrm{Si}$ & 915.6 & 918.5 & $4.8: 1$
\end{tabular}

${ }^{a}$ Peak area ratios of $\mathrm{Cu}^{+}$to $\mathrm{Cu}^{0}$ were calculated by the deconvolution of $\mathrm{Cu}$ LMM XAES.

932.4 and $952.3 \mathrm{eV}$, respectively, indicating that metallic $\mathrm{Cu}^{0}$ and/or $\mathrm{Cu}^{+}$species were present (Fig. 6b). The presence of a weak satellite peak at $942.5 \mathrm{eV}$ for the reacted $\mathrm{Cu}_{2} \mathrm{O} / \mathrm{Si}$ and reacted $\mathrm{CuO} / \mathrm{Si}$ mixtures indicated that there was a trace amount of $\mathrm{Cu}^{2+}$ species present. However, the absence of the satellite peak in the reacted $\mathrm{Cu} / \mathrm{Si}$ mixture indicated that no $\mathrm{Cu}^{2+}$ species existed.

To ascertain the chemical states of the surface copper species, the XAES peaks were deconvoluted (Fig. 7). Using Gaussian-Lorentzian bands with the peak positions at $\mathrm{ca} .916$ and $918.7 \mathrm{eV}$ for $\mathrm{Cu}^{+}$and $\mathrm{Cu}^{0}$ and at $c a .912 \mathrm{eV}$ for other orbital electrons, the XAES peaks were deconvoluted into three symmetrical peaks. ${ }^{13,16,18-20}$

According to the deconvolution results, the surface copper species of the reacted $\mathrm{Cu} / \mathrm{Si}$, reacted $\mathrm{Cu}_{2} \mathrm{O} / \mathrm{Si}$, and reacted $\mathrm{CuO} /$ Si mixtures were mainly composed of $\mathrm{Cu}^{+}$and metallic $\mathrm{Cu}^{0}$ components. During the reaction process, $\mathrm{Cu}^{+}$and $\mathrm{Cu}^{2+}$ species in the $\mathrm{Cu}_{2} \mathrm{O} / \mathrm{Si}$ and $\mathrm{CuO} / \mathrm{Si}$ mixtures were reduced to copper species with lower valence states. The ratios of surface $\mathrm{Cu}^{+}$to $\mathrm{Cu}^{0}$ were influenced by their copper precursors (Table 2).

\subsection{Direct reaction of silicon with methanol over $\mathrm{CuCl}$ catalyst}

3.3.1. Effect of pretreatment temperature. The results of the reaction between silicon and methanol over a $\mathrm{CuCl}$ catalyst pretreated in a $\mathrm{N}_{2}$ atmosphere at different temperatures are listed in Table 3. Trimethoxysilane and tetramethoxysilane were detected as the main products. The conversion of methanol increased upon increasing the pretreatment temperature, probably due to the possibility that high pretreatment temperature promoted the interaction between $\mathrm{CuCl}$ and silicon, providing more active sites for the reaction between silicon and methanol. Interestingly, it was found that the trimethoxysilane selectivity at the pretreatment temperatures of $200-240{ }^{\circ} \mathrm{C}$ was higher than that at $260-340{ }^{\circ} \mathrm{C}$. When the pretreatment temperature was more than $280{ }^{\circ} \mathrm{C}$, the trimethoxysilane selectivity was less than the tetramethoxysilane selectivity. Combining the XRD, XPS, and XAES analyses, it was suggested that the $\mathrm{Cu}_{x} \mathrm{Si}_{y} \mathrm{Cl}_{z}$ species formed in the pretreatment process played an important role for the formation of trimethoxysilane. The surface $\mathrm{Cu}^{+}$and metallic $\mathrm{Cu}^{0}$ species probably co-catalyzed the formation of tetramethoxysilane.

3.3.2. Effect of CuCl loading. Considering that a lower pretreatment temperature gave high selectivity of trimethoxysilane, the $\mathrm{CuCl} / \mathrm{Si}$ mixtures pretreated at $200{ }^{\circ} \mathrm{C}$ were used to investigate the effect of $\mathrm{CuCl}$ loading on the reaction between silicon and methanol. The reaction results are listed in Table 4 .

Table 3 Direct reaction between silicon and methanol over CuCl catalyst pretreated at different temperatures ${ }^{a}$

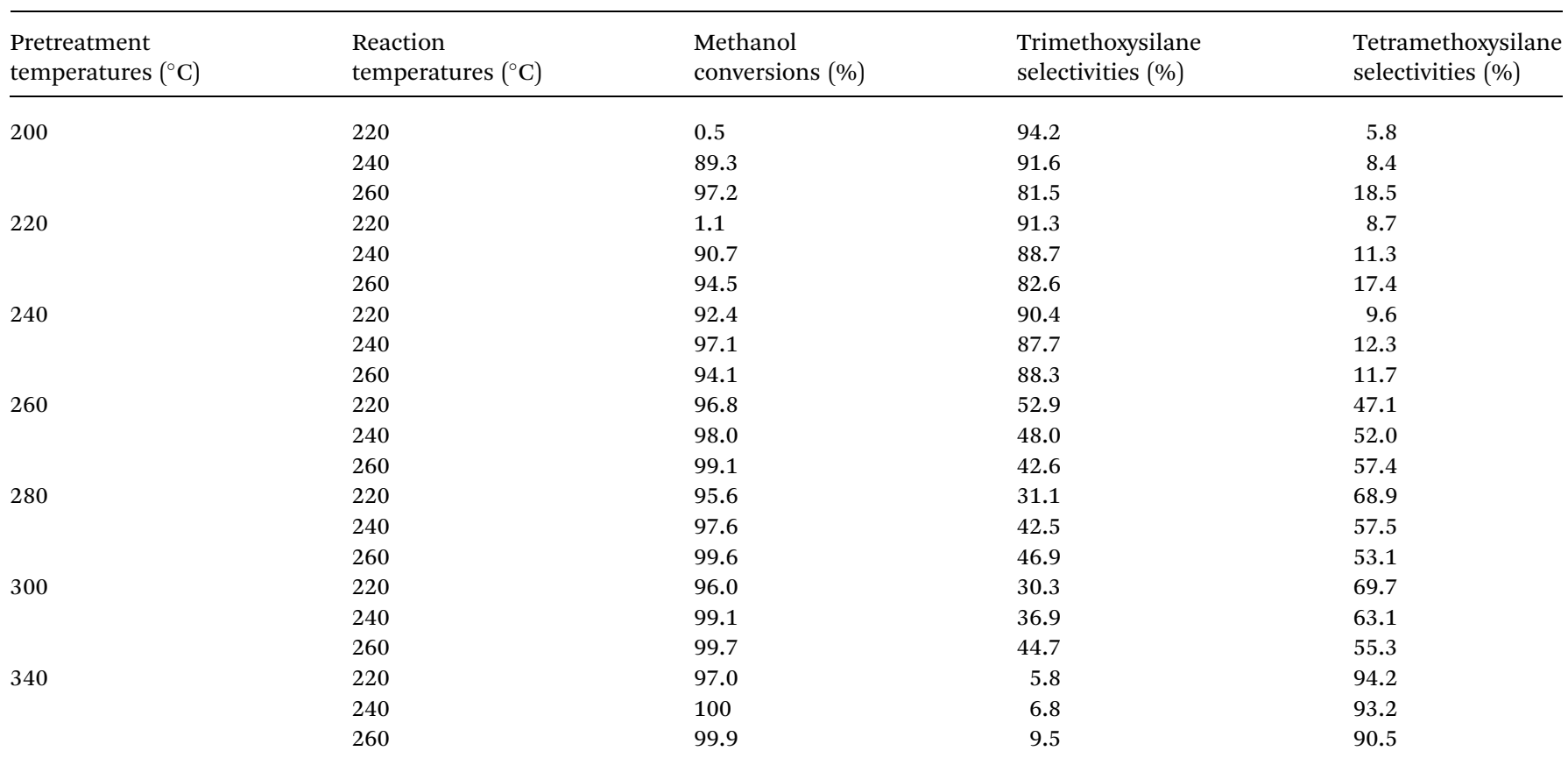

${ }^{a}$ The reaction mixtures of silicon and $\mathrm{CuCl}$ were pretreated at different temperatures for $2 \mathrm{~h}$ in a $\mathrm{N}_{2}$ stream with a flow rate of $20 \mathrm{~mL}$ min ${ }^{-1}$. The mixture of $\mathrm{CuCl}$ and silicon was $40 \mathrm{~g}$, the $\mathrm{CuCl} / \mathrm{Si}$ weight ratio was $8: 100$, and the methanol flow rate was $6 \mathrm{~mL} \mathrm{~h}^{-1}$. 
Table 4 Direct reaction between silicon and methanol over $\mathrm{CuCl}$ catalyst with different $\mathrm{CuCl}$ loadings ${ }^{a}$

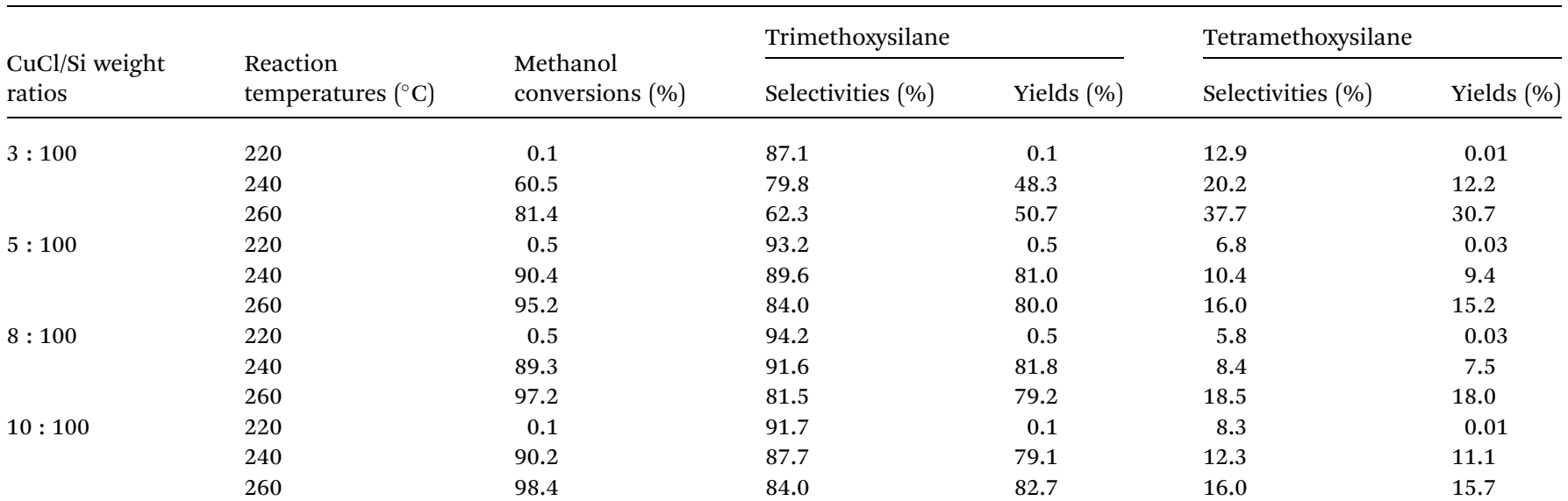

${ }^{a}$ The $\mathrm{CuCl} / \mathrm{Si}$ mixtures were pretreated at $200{ }^{\circ} \mathrm{C}$ for $2 \mathrm{~h}$ in a $\mathrm{N}_{2}$ stream with a flow rate of $20 \mathrm{~mL} \mathrm{~min}{ }^{-1}$. The $\mathrm{CuCl} / \mathrm{Si}$ mixture was $40 \mathrm{~g}$ and the methanol flow rate was $6 \mathrm{~mL} \mathrm{~h}^{-1}$.

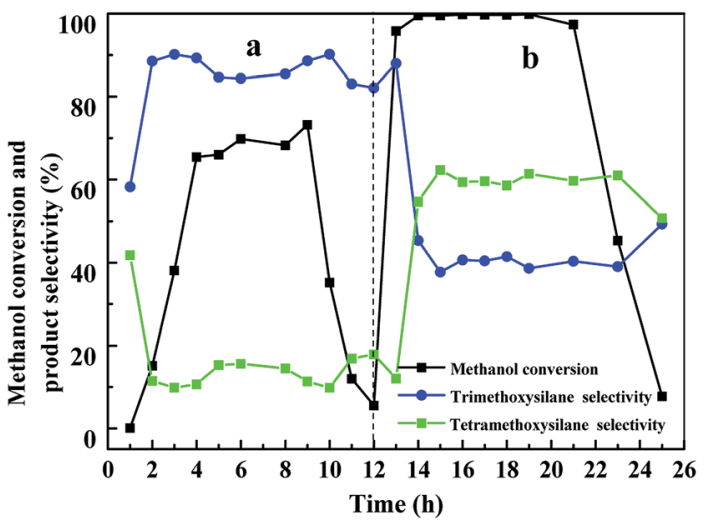

Fig. 8 Reaction between silicon and methanol at $240{ }^{\circ} \mathrm{C}$ with a methanol flow rate of $6 \mathrm{~mL} \mathrm{~h}^{-1}$. Reaction conditions: (a) The CuCl/Si mixture was not pretreated before reaction. The amount of $\mathrm{CuCl} / \mathrm{Si}$ mixture was $40 \mathrm{~g}$ with a $\mathrm{CuCl} /$ silicon weight ratio of $8: 100$. (b) The spent $\mathrm{CuCl} / \mathrm{Si}$ mixture was chlorinated with $\mathrm{HCl}\left(40 \mathrm{~mL} \mathrm{~min}^{-1}\right)$ at $280{ }^{\circ} \mathrm{C}$ for $1.5 \mathrm{~h}$ before reaction.

The reaction results showed that upon increasing the $\mathrm{CuCl}$ loading and reaction temperature, the conversion of methanol increased. When the $\mathrm{CuCl}$ loadings were $5-10 \%$ at the reaction temperatures of $240-260{ }^{\circ} \mathrm{C}$, the trimethoxysilane yield of $c a$. $80 \%$ was obtained.

3.3.3. Reaction life time and $\mathrm{HCl}$ treatment. Without pretreatment, the methanol conversion increased with prolonging reaction time during the first $4 \mathrm{~h}$ (Fig. 8a). The methanol conversion remained at $c a .70 \%$ for $5 \mathrm{~h}$. Then the methanol conversion decreased rapidly to $5.5 \%$ in $3 \mathrm{~h}$. The selectivities of trimethoxysilane and tetraethoxysilane remained at ca. 85\% and $15 \%$ during the reaction time period, respectively.

When the spent $\mathrm{CuCl} / \mathrm{Si}$ mixture was chlorinated with $\mathrm{HCl}$, the conversion of methanol increased to 95\% during the first $1 \mathrm{~h}$ and remained at above $99 \%$ for $9 \mathrm{~h}$ (Fig. $8 \mathrm{~b}$ ). Then the methanol conversion decreased to $7.7 \%$ in $3 \mathrm{~h}$. The selectivities of trimethoxysilane and tetramethoxysilane remained at $c a$. $40 \%$ and $60 \%$, respectively.

The results revealed that without pretreatment, the reaction rate between silicon and methanol increased gradually with reaction time. The main product was trimethoxysilane. When the spent $\mathrm{CuCl} / \mathrm{Si}$ mixture was chlorinated with $\mathrm{HCl}$, the reaction rate between silicon and methanol rapidly increased, probably due to the formation of more $\mathrm{Cu}_{x} \mathrm{Si}_{y} \mathrm{Cl}_{z}$ active sites and the exposure of the metallic $\mathrm{Cu}^{0}$ active sites. However, after chlorination with $\mathrm{HCl}$, the selectivity of trimethoxysilane was one half that using a fresh $\mathrm{CuCl} / \mathrm{Si}$ mixture, indicating that the exposed metallic $\mathrm{Cu}^{0}$ probably promoted the formation of tetramethoxysilane.

\subsection{Direct reaction of silicon with methanol over $\mathrm{Cu}_{2} \mathrm{O}$, $\mathrm{CuO}$, and metallic $\mathrm{Cu}^{0}$ catalysts}

When $\mathrm{Cu}_{2} \mathrm{O}, \mathrm{CuO}$, and bulk metallic $\mathrm{Cu}^{0}$ were used as the catalysts, tetramethoxysilane was formed as the main product. The $\mathrm{Cu}_{2} \mathrm{O}$ and $\mathrm{CuO}$ catalysts exhibited higher catalytic activities for the reaction between silicon and methanol than the bulk metallic $\mathrm{Cu}^{0}$ catalyst (Table 5). This suggested that the surface $\mathrm{Cu}^{+} / \mathrm{Cu}^{0}$ species co-catalyzed the reaction between silicon and methanol to form tetramethoxysilane.

It was interesting to discover that a small amount of methyl formate was formed as the by-product over the $\mathrm{Cu}_{2} \mathrm{O}$ and $\mathrm{CuO}$ catalysts. While using the bulk metallic $\mathrm{Cu}^{0}$ as the catalyst, a small amount of trimethoxysilane was formed as the byproduct. According to the crystallite sizes of the metallic $\mathrm{Cu}^{0}$, the high catalytic activities over the $\mathrm{Cu}_{2} \mathrm{O}$ and $\mathrm{CuO}$ catalysts were due to the formation of small-sized metallic $\mathrm{Cu}^{0}$ crystallites in the reaction. The small-sized metallic $\mathrm{Cu}^{0}$ crystallites also catalyzed the formation of methyl formate via the intermolecular dehydrogenation reaction of methanol. ${ }^{21}$

$$
2 \mathrm{CH}_{3} \mathrm{OH}=\mathrm{CH}_{3} \mathrm{OOCH}+2 \mathrm{H}_{2}
$$




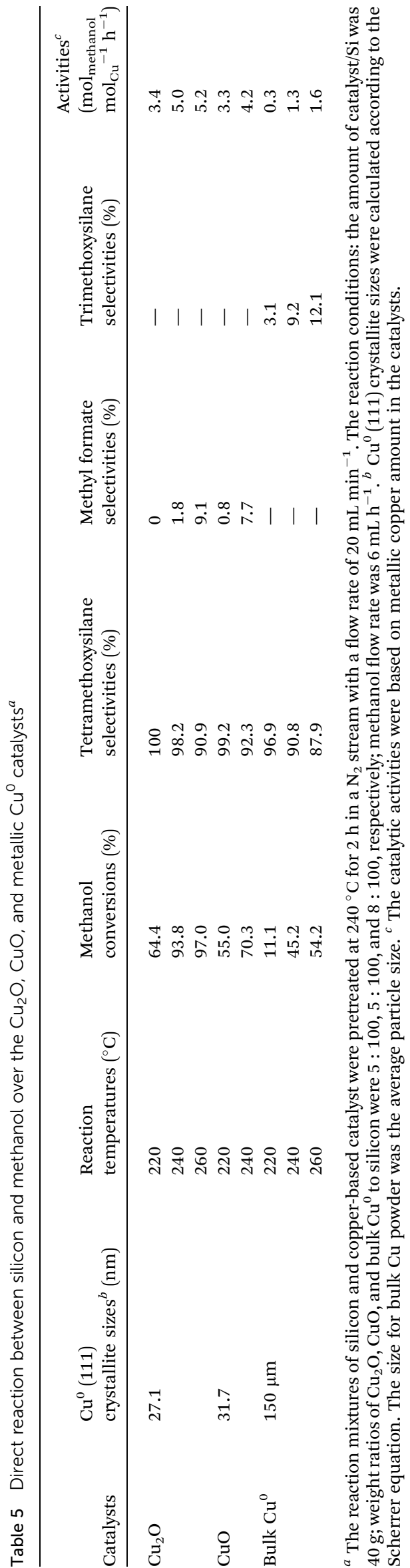

\section{Conclusions}

In the direct reaction of silicon with methanol over a $\mathrm{CuCl}$ catalyst, pretreatment temperature affected the evolution of the $\mathrm{Cu}_{x} \mathrm{Si}_{y} \mathrm{Cl}_{z}$ species, metallic $\mathrm{Cu}^{0}$, and $\mathrm{Cu}_{3} \mathrm{Si}$ phases. The $\mathrm{Cu}_{x} \mathrm{Si}_{y} \mathrm{Cl}_{z}$ species appeared at a lower pretreatment temperature, whereas the $\mathrm{Cu}_{3} \mathrm{Si}$ phase appeared at a pretreatment temperature of $280{ }^{\circ} \mathrm{C}$ or higher.

After pretreating $\mathrm{CuCl} / \mathrm{Si}(5: 100-10: 100)$ mixtures at the pretreatment temperature of $200{ }^{\circ} \mathrm{C}$, trimethoxysilane was predominantly formed with a yield $c a .80 \%$ at methanol conversion of more than $89 \%$ and reaction temperatures of 240-260 ${ }^{\circ} \mathrm{C}$. The $\mathrm{Cu}_{x} \mathrm{Si}_{y} \mathrm{Cl}_{z}$ species catalyzed the formation of trimethoxysilane. After pretreating the $\mathrm{CuCl} / \mathrm{Si}$ mixture at a pretreatment temperature of above $280^{\circ} \mathrm{C}$, tetramethoxysilane was favorably formed. The surface $\mathrm{Cu}^{+}$and metallic $\mathrm{Cu}^{0}$ phases catalyzed the formation of tetramethoxysilane.

Chlorination of the spent $\mathrm{CuCl} / \mathrm{Si}$ mixture promoted the reaction between silicon and methanol to the formation of trimethoxysilane and tetraethoxysilane, probably due to the recovery of the $\mathrm{Cu}_{x} \mathrm{Si}_{y} \mathrm{Cl}_{z}$ active species and the exposure of metallic $\mathrm{Cu}^{0}$ species.

When the direct reaction was catalyzed over $\mathrm{Cu}_{2} \mathrm{O}$ and $\mathrm{CuO}$ catalysts, the $\mathrm{Cu}_{2} \mathrm{O}$ and $\mathrm{CuO}$ phases were reduced to the metallic $\mathrm{Cu}^{0}$ phase during the reaction process. Tetramethoxysilane was formed as the main product with a selectivity of more than $90 \%$ at the reaction temperatures of $220-260{ }^{\circ} \mathrm{C}$. $\mathrm{Cu}_{2} \mathrm{O}$ and $\mathrm{CuO}$ catalysts exhibited higher catalytic activities for the direct reaction than the bulk metallic $\mathrm{Cu}^{0}$ catalyst. The surface $\mathrm{Cu}^{+}$and metallic $\mathrm{Cu}^{0}$ co-catalyzed the formation of tetraethoxysilane.

\section{Conflicts of interest}

There are no conflicts to declare.

\section{Acknowledgements}

This work was financially supported by the National Natural Science Foundation of China (21506078) and China Postdoctoral Science Foundation (2016M601739).

\section{References}

1 M. Okamoto, J. Komai, M. Uematsu, E. Suzuki and Y. Ono, J. Organomet. Chem., 2001, 619, 235-240.

2 M. Okamoto, J. Komai, M. Uematsu, E. Suzuki and Y. Ono, J. Assoc. Arab Univ. Basic Appl. Sci., 2012, 12, 27-32.

3 J. S. Han, J. H. Cho, M. E. Lee and B. R. Yoo, Bull. Korean Chem. Soc., 2009, 30, 683-686.

4 L. Zhang, J. Li, K. Yang, C. Hu, S. Ge and C. Yang, Adv. Mater. Res., 2011, 233-235, 1534-1539.

5 M. Okamoto, M. Osaka, K. Yamamoto, E. Suzuki and Y. Ono, J. Catal., 1993, 143, 64-85.

6 E. Suzuki, M. Okamoto and Y. Ono, Chem. Lett., 1991, 199202.

7 E. Suzuki and Y. Ono, J. Catal., 1990, 125, 390-400. 
8 M. Okamoto, E. Suzuki and Y. Ono, J. Catal., 1994, 145, 537543.

9 N. Y. Adonin, S. A. Prikhod'ko, A. Y. Shabalin, I. P. Prosvirin, V. I. Zaikovskii, D. I. Kochubey, D. A. Zyuzin, V. N. Parmon, E. A. Monin, I. A. Bykova, P. O. Martynov, S. L. Rusakov and P. A. Storozhenko, J. Catal., 2016, 338, 143-153.

10 M. Okamoto, N. Mimura, E. Suzuki and Y. Ono, Catal. Lett., 1995, 33, 421-427.

11 B. Gillot, G. Weber, H. Souha and M. Zenkouar, J. Alloys Compd., 1998, 270, 275-280.

12 R. Zhang, H. Yin, D. Zhang, L. Qi, H. Lu, Y. Shen and T. Jiang, Chem. Eng. J., 2008, 140, 488-496.

13 W.-L. Dai, Q. Sun, J.-F. Deng, D. Wu and Y.-H. Sun, Appl. Surf. Sci., 2001, 177, 172-179.
14 O. Baghriche, S. Rtimi, C. Pulgarin and J. Kiwi, Catal. Today, 2017, 284, 77-83.

15 H. Liu, J. Xie, P. Liu and B. Dai, Catalysts, 2016, 6, 120.

16 C. L. Aravinda, P. Bera, V. Jayaram, A. K. Sharma and S. M. Mayanna, Mater. Res. Bull., 2002, 37, 397-405.

17 K. V. Rajani, S. Daniels, P. J. McNally and S. Krishnamurthy, J. Phys.: Condens. Matter, 2013, 25, 285501-285506.

18 K. L. Deutsch and B. H. Shanks, J. Catal., 2012, 285, 235-241.

19 K. Sun, W. Lu, F. Qiu, S. Liu and X. Xu, Appl. Catal., A, 2003, 252, 243-249.

20 Z. He, H. Lin, P. He and Y. Yuan, J. Catal., 2011, 277, 54-63.

21 Z. Lu, D. Gao, H. Yin, A. Wang and S. Liu, J. Ind. Eng. Chem., 2015, 31, 301-308. 